\title{
Pengaruh Praktek Good Coorporate Governance terhadap Nilai Perusahaan Perbankan di Indonesia
}

\author{
Yossi Eko Sriyanto Putra \\ Fakultas Ekonomika dan Bisnis Jurusan Akuntansi-Universitas Kristen Satya Wacana \\ 232011169@student.uksw.edu \\ Elisabeth Penti Kurniawati \\ Fakultas Ekonomika dan Bisnis Jurusan Akuntansi-Universitas Kristen Satya Wacana \\ bet@staff.uksw.edu
}

\begin{abstract}
Bank Indonesia has ever imposed sanctions against several banks in Indonesia for not implementing good corporate governance. This case will certainly affect the public perception of the value of banking companies in Indonesia. The objective of this research is to analyze the effect of Good Corporate Governance on Company Value on the banking sector listed on the Indonesia Stock Exchange in a period of 2012-2014. The components of good corporate governance used in this study are the Institutional Ownership, Managerial Ownership, Audit Committee, and Independent Commissioner. The Company Value is measured by Tobin's $Q$. The sampling method in this research is a purposive sampling method. This study uses secondary data in the form of annual reports obtained from the website of the Indonesia Stock Exchange. Hypothesis testing in this study uses multiple linear regression analysis technique. The results show that good corporate governance does not affect the company value in the banking sector companies. Nevertheless, this study may indicate that good corporate governance is essential for the company, though not enough to affect the value of a company.
\end{abstract}

Keywords: Good Corporate Governance (GCG); Company Value

\section{Pendahuluan}

Perkembangan penerapan praktek Good Corporate Governance (GCG) di Indonesia masih rendah. Berdasarkan Market Rangkings dari Asian Corporate Governance Association pada tahun 2014 Indonesia masih menempati peringkat terendah di bawah Filipina (Jamie, 2014). Rendahnya praktek GCG juga berdampak pada industri perbankan di Indonesia. Bank Indonesia pernah menetapkan sanksi terhadap 4 (empat) bank berupa pembatasan lantaran keempat bank tersebut tak menerapkan GCG (Qorib, 2013). Dengan adanya kasus tersebut, persepsi masyarakat terhadap nilai perusahaan perbankan yang terlibat akan terpengaruh. 
Penelitian Randy dan Juniarti (2014) menyatakan bahwa GCG berpengaruh signifikan terhadap nilai perusahaan, sedangkan penelitian Lutfiah (2012) menyimpulkan bahwa GCG berpengaruh negatif terhadap nilai perusahaan. Penelitan ini akan menguji pengaruh GCG terhadap nilai perusahaan perbankan dengan menambahkan variabel kontrol berupa total aset perusahaan.

\section{Kerangka Pemikiran dan Hipotesis}

\section{Kepemilikan Institusional}

Kepemilikan institusional adalah kepemilikan jumlah saham oleh perusahaan atau institusi lain. Investor institusional semestinya lebih dapat menggunakan informasi perusahaan dalam memprediksi laba masa depan dibanding investor non instusional. Balsam, Bartov, dan Marquardt (2002) menyatakan bahwa investor institusional mempunyai akses atas sumber informasi yang lebih tepat waktu dan relevan yang dapat mengetahui keberadaan pengelolaan laba lebih cepat dan lebih mudah dibandingkan investor individual. Investor institusional dianggap memiliki kemampuan untuk mengendalikan pihak manajemen melalui proses monitoring secara efektif yang dapat menaikkan kinerja perusahaan sehingga akan menarik banyak investor untuk menanamkan saham ke dalam perusahaan dengan demikian nilai perusahaan juga akan meningkat. Berdasarkan hal tersebut hipotesa yang diajukan adalah:

H1 : Kepemilikan institusional berpengaruh positif terhadap nilai perusahaan.

\section{Kepemilikan Manajerial}

Jensen dan Meckling (1976) menemukan bahwa kepemilikan manajerial berhasil menjadi mekanisme untuk mengurangi masalah keagenan dari manajer dengan menyelaraskan kepentingan-kepentingan manajer dengan pemegang saham. Penelitian mereka menemukan bahwa kepentingan manajer dengan pemegang saham eksternal dapat disatukan jika kepemilikan saham oleh manajer diperbesar sehingga manajer tidak akan memanipulasi laba untuk kepentingannya. Rachman (2012) dalam penelitianya menyatakan bahwa meningkatnya kepemilikan manajerial akan berdampak positif terhadap nilai perusahaan, karena dengan bertambahnya kepemilikan saham oleh pihak manajemen perusahaan maka kontrol pada aktivitas manajemen akan meningkat. Dengan demikian setiap aktivitas dan keputusan perusahaan akan optimal sehingga kinerja perusahaan meningkat. Dengan naiknya kinerja perusahaan, calon investor akan melihat adanya nilai tambah pada perusahaan sehingga banyak investor yang akan menanamkan modalnya ke dalam perusahaan di mana hal ini akan meningkatkan nilai perusahaan. Hal ini juga diperkuat oleh penelitian Ningsih (2013) yang menemukan bahwa semakin besar proporsi kepemilikan manajerial, maka nilai perusahaan akan meningkat. Berdasarkan hal tersebut hipotesa yang diajukan adalah:

H2 : Kepemilikan manajerial berpengaruh positif terhadap nilai perusahaan

\section{Komisaris Independen}

Komisaris independen merupakan dewan komisaris yang memiliki peranan sebagai pengawas yang independen di dalam perusahaan agar tidak terjadi kecurangan. Dengan adanya komisaris independen dimaksudkan agar tidak ada pihak yang merasa dirugikan dan tujuan perusahaan dapat tercapai dengan diterapkanya tata kelola perusahaan yang baik, sehingga masalah keagenan akan berkurang. Ketika masalah keagenan berkurang manajemen laba juga akan berkurang hal ini akan berpengaruh terhadap meningkatnya 
kepercayaan investor dan berdampak pada naiknya harga saham perusahaan dan pada akhirnya nilai perusahaan juga akan meningkat. Pernyataan ini juga didukung oleh hasil penelitian dari Purwaningtyas dan Pangestuti (2010) yang menyatakan bahwa adanya pengaruh positif-signifikan antara komisaris independen terhadap nilai perusahaan. Berdasarkan hal tersebut hipotesa yang diajukan adalah:

H3 : Komisaris independen berpengaruh positif terhadap nilai perusahaan

\title{
Komite Audit
}

Menurut Salim (2005) komite audit merupakan salah satu persyaratan untuk menerapkan Good Corporate Governance. Komite audit dibentuk sebagai sebuah komite khusus yang diharapkan dapat mengoptimalkan fungsi pengawasan Tugas komite audit meliputi melakukan pengawasan terhadap laporan keuangan, audit eksternal dan sistem pengendalian internal. Ketika komite audit menjalankan tugasnya dengan baik maka pengawasan menjadi lebih baik sehingga kinerja perusahaan meningkat. Hal ini akan mempengaruhi minat investor untuk menanamkan saham ke dalam sebuah perusahaan yang akan menaikkan harga saham sehingga nilai perusahaan meningkat. Berdasarkan hal tersebut hipotesa yang diajukan adalah:

$\mathrm{H} 4$ : Komite audit berpengaruh positif terhadap nilai perusahaan

\section{Kerangka Teoritis}

\begin{abstract}
Agency Theory
Perspektif teori agensi merupakan dasar yang digunakan untuk memahami isu Corporate Governance (CG). Adanya pemisahan kepemilikan oleh principal dengan pengendalian oleh agen dalam sebuah organisasi cenderung menimbulkan konflik keagenan diantara principal dan agen. Jensen dan Meckling (1976) menyatakan bahwa laporan keuangan yang dibuat dengan angka-angka akuntansi diharapkan dapat meminimalkan konflik diantara pihak-pihak yang berkepentingan. Dengan laporan keuangan yang dilaporkan oleh agen sebagai pertanggungjawaban kinerjanya, principal dapat menilai, mengukur dan mengawasi sampai sejauh mana agen tersebut bekerja untuk meningkatkan kesejahteraannya serta sebagai dasar pemberian kompensasi kepada agen.

CG berkaitan dengan bagaimana investor yakin bahwa manajer akan memberikan keuntungan bagi investor, yakin bahwa manajer tidak akan mencuri, menggelapkan atau menginvestasikan ke dalam proyek-proyek yang tidak menguntungkan berkaitan dengan dana ataupun kapital yang telah ditanamkan oleh investor dan berkaitan dengan bagaimana para investor mengendalikan para manajer (Sheifer dan Vishny, 1997).
\end{abstract}

\section{Good Corporate Governance (GCG)}

Mekanisme GCG merupakan suatu aturan main, prosedur dan hubungan yang jelas antara pihak yang mengambil keputusan dengan yang melakukan kontrol/ pengawasan terhadap keputusan tersebut. Mekanisme corporate governance diarahkan untuk menjamin dan mengawasi berjalannya sistem governance dalam sebuah organisasi (Walsh dan Seward, 1990). Menurut Boediono (2005) mekanisme corporate governance merupakan suatu sistem yang mampu mengendalikan dan mengarahkan kegiatan operasional perusahaan serta pihak-pihak yang terlibat di dalamnya, sehingga dapat digunakan untuk menekan terjadinya masalah agency. Maka untuk meminimalkan 
konflik kepentingan antara principal dan agent akibat adanya pemisahan pengelolaan perusahaan, diperlukan suatu cara efektif untuk mengatasi konflik kepentingan tersebut.

Penelitian Zulkifli dan Samad (2007) mengkaji mekanisme tata kelola perusahaan dalam mengukur kinerja perusahaan perbankan melalui Mekanisme Pemantauan Kepemilikan (Ownership), Mekanisme Pemantauan Pengendalian Internal dan Mekanisme Pemantauan Pengungkapan.

\section{Mekanisme Pemantauan Kepemilikan}

Mekanisme pemantauan adalah sebuah sistem yang digunakan untuk melihat kinerja sebuah perusahaan melalui struktur kepemilikan modal di dalam perusahaan (Listyo, 2013). Struktur kepemilikan di dalam penelitian ini menggunakan (1) kepemilikan institusional dan (2) kepemilikan manajerial.

Kepemilikan institusional merupakan presentase saham yang dimiliki oleh pihak institusi perusahaan pada akhir tahun (Wahidahwati, 2002). Faisal (2005) menyatakan bahwa kepemilikan institusional merupakan pihak yang memonitor perusahaan. Kepemilikan institusional di dalam suatu perusahaan mempunyai arti penting dalam memonitor manajemen dalam mengelola perusahaan. Semakin tinggi tingkat kepemilikan institusional maka semakin besar pengawasan oleh pihak investor institusional sehingga dapat menghalangi perilaku oportunistik yang dilakukan oleh manajer. Kepemilikan institusional diukur dengan presentase jumlah saham yang dimiliki oleh investor institusional dibandingkan dengan total saham perusahaan.

Kepemilikan manajerial adalah pemegang saham dari pihak manajemen (direktur dan komisaris) yang secara aktif ikut dalam pengambilan keputusan (Wahidahwati, 2002). Menurut Jensen dan Meckling (1976) serta Morck, Shleifer dan Vishny (1988), kepentingan manajer dan pemegang saham dapat diselaraskan bila manajer memiliki saham perusahaan yang lebih besar. Dengan manajer terlibat dalam kepemilikan saham dapat mengurangi adanya asimetri informasi di dalam suatu perusahaan sekaligus dapat meningkatkan kinerja manajer. Kepemilikan manajemen diukur dengan persentase jumlah saham yang dimiliki pihak manajemen dari dibandingkan dengan seluruh modal saham perusahaan yang beredar.

\section{Mekanisme Pemantauan Pengendalian Internal}

Mekanisme pemantauan pengendalian internal adalah salah satu mekanisme Good Corporate Governance yang dilakukan oleh pihak internal perusahaan, dalam hal ini dewan komisaris. Menurut Peraturan Bank Indonesia Nomor 8/4/PBI/2006 tentang Pelaksanaan Good Corporate Governance bagi Bank Umum, jumlah anggota dewan komisaris pada perusahaan perbankan paling kurang 3 (tiga) orang dan paling banyak sama dengan jumlah anggota direksi. Dewan komisaris terdiri dari komisaris dan komisaris independen. Keberadaan komisaris independen dimaksudkan untuk mendorong terciptanya iklim dan lingkungan kerja yang lebih obyektif dan menempatkan kewajaran (fairness) dan kesetaraan di antara berbagai kepentingan termasuk kepentingan pemegang saham minoritas dan stakeholders lainnya.

Berdasarkan Peraturan Bank Indonesia Nomor 8/4/PBI/2006, komisaris independen adalah anggota dewan komisaris yang tidak memiliki hubungan keuangan, kepengurusan, kepemilikan saham atau hubungan keluarga dengan anggota dewan komisaris lainnya, direksi atau pemegang saham pengendali atau hubungan lain yang dapat mempengaruhi kemampuannya untuk bertindak independen. Di Indonesia saat ini, keberadaan komisaris independen sudah diatur dalam Code of Good Corporate Governance. Menurut Code tersebut, komisaris bertanggung jawab dan mempunyai 
kewenangan untuk mengawasi kebijakan dan kegiatan yang dilakukan direksi dan memberikan nasihat jika diperlukan. Keberadaan komisaris independen diukur dengan persentase jumlah anggota dewan komisaris independen dibandingkan dengan seluruh anggota dewan komisaris.

\section{Mekanisme Pemantauan Pengungkapan}

Mekanisme pemantauan pengungkapan menurut Listyo (2013) adalah sebuah sistem yang dibentuk untuk mengawasi pengelolaan sebuah perusahaan, yang di dalamnya terdiri dari komite audit. Komite audit dibentuk oleh dewan komisaris untuk melakukan pengendalian internal di dalam suatu perusahaan.

Komite audit berdasarkan keputusan ketua BAPEPAM Kep. 29/PM/2004 adalah komite yang dibentuk oleh dewan komisaris untuk melakukan tugas pengawasan pengelolaan perusahaan. Komite audit merupakan penghubung antara pemegang saham dan dewan komisaris dengan pihak manajemen dalam menangani masalah pengendalian anggota lain yang bukan merupakan komisaris independen harus berasal dari pihak eksternal yang independen. Komite audit dalam penelitian ini diukur menggunakan skala rasio melalui presentase anggota komite audit terhadap seluruh anggota dewan komisaris (Isnanta, 2008, dalam Sari, 2010).

\section{Asas $G C G$ pada Perusahaan Perbankan}

Menurut prinsip dasar pedoman GCG Perbankan Indonesia (2013), setiap bank harus memastikan bahwa asas GCG diterapkan pada setiap aspek bisnis dan di seluruh jajaran bank. Asas GCG tersebut meliputi transparansi, akuntabilitas, responsibilitas, indepedensi serta kewajaran dan kesetaraan. Asas GCG diperlukan untuk mencapai kesinambungan usaha (sustainability) bank dengan memperhatikan kepentingan pemegang saham, nasabah serta pemangku kepentingan lainnya.

\section{Nilai Perusahaan}

Nilai perusahaan adalah kondisi tertentu yang telah dicapai sebuah perusahaan, sebagai gambaran yang telah dipercaya masyarakat. Salah satu alternatif yang dapat digunakan untuk mengukur nilai perusahaan adalah rasio Tobin's Q, yang dikembangkan oleh James Tobin pada tahun 1967. Rasio ini menunjukkan estimasi pasar keuangan saat ini tentang nilai hasil pengembalian dari setiap dolar (rupiah) investasi inkremental. Rasioq mengukur seberapa efektif manajemen memanfaatkan sumber-sumber daya ekonomis dalam kekuasaannya. Jika rasio-q di atas satu artinya investasi dalam aktiva menghasilkan laba yang memberikan nilai yang lebih tinggi daripada pengeluaran investasi.

\section{Corporate Governance dan Nilai Perusahaan}

Dalam perspektif teori agensi, agen yang cenderung menghindari risiko dan mementingkan dirinya sendiri akan mengalokasikan sumber daya dari investasi yang tidak meningkatkan nilai perusahaan ke alternatif investasi yang lebih menguntungkan. Permasalahan agensi akan mengindikasikan bahwa nilai perusahaan akan naik apabila pemilik perusahaan bisa mengendalikan perilaku manajemen agar tidak menghamburkan sumber daya perusahaan, baik dalam bentuk investasi yang tidak layak maupun dalam bentuk kelalaian investasi.

Corporate Governance merupakan suatu sistem yang mengatur dan mengendalikan perusahaan yang diharapkan dapat memberikan dan meningkatkan nilai perusahaan bagi para pemegang saham. Dengan demikian, penerapan Good Corporate 
Governance dipercaya dapat meningkatkan nilai perusahaan. Silveira dan Barros (2006) meneliti pengaruh kualitas Corporate Governance terhadap nilai pasar perusahaan di Brazil. Temuan yang diperoleh menunjukkan adanya pengaruh kualitas CG yang positif dan signifikan terhadap nilai pasar perusahaan. Sedangkan Black, Jang, and Kim (2003) menyatakan bahwa Corporate Governance Index secara keseluruhan merupakan hal penting dan menjadi salah satu faktor penyebab yang dapat menjelaskan nilai pasar bagi perusahaan-perusahaan independen di Korea.

\section{Metode Penelitian}

Penelitian ini merupakan penelitian kuantitatif. Populasi dalam penelitian ini adalah semua perusahaan perbankan yang terdaftar di Bursa Efek Indonesia (BEI). Pengambilan sampel dilakukan dengan menggunakan Purposive Sampling dengan kriteria sebagai berikut: 1) terdaftar di BEI tahun 2011-2014; 2) menerbitkan laporan tahunan yang berakhir pada tanggal 31 Desember yang telah diaudit. Berdasarkan kriteria tersebut, jumlah sampel yang digunakan adalah 27 perusahaan selama 3 tahun, sehingga total data observasi adalah 81 .

Penelitian ini menggunakan data sekunder berupa laporan tahunan perusahaan yang diperoleh dari situs BEI. Data yang digunakan meliputi data-data yang terkait dengan nilai perusahaan dan Good Corporate Governance, yang meliputi komisaris independen, kepemilikan manajerial, kepemilikan institusional, dan kualitas audit.

\section{Operasionalisasi Variabel}

GCG sebagai variabel independen diproksi dengan komisaris independen, kepemilikan manajerial, kepemilikan institusional dan kualitas audit, sebagai berikut:

(1) Kepemilikan institusional diukur dengan besarnya jumlah saham yang dimiliki investor institusional dari seluruh total modal saham yang beredar. Kepemilikan institusional diproksikan dengan skala pengukuran rasio sebagai berikut:

$$
\text { KEPIN }=\quad \frac{\text { Jumlah saham yang dimiliki investor institusional }}{\text { Total modal saham yang beredar }}
$$

(2) Kepemilikan manajerial diukur dengan besarnya jumlah saham yang dimiliki manajemen dari seluruh total saham yang beredar. Kepemilikan manajerial diproksikan dengan skala pengukuran rasio sebagai berikut:

$$
\text { KEPMAN }=\frac{\text { Jumlah saham yang dimiliki pihak manajemen }}{\text { Seluruh modal saham perusahaan yang beredar }}
$$

(3) Komisaris independen diukur dengan besarnya jumlah anggota dewan komisaris independen dari seluruh anggota dewan komisaris di dalam perusahaan. Komisaris independen diproksikan dengan skala pengukuran rasio sebagai berikut:

KOMIN $=\frac{\text { Jumlah anggota dewan komisaris independen }}{\text { Seluruh anggota dewan komisaris }}$


(4) Komite audit diukur dengan besarnya jumlah anggota komite audit dari seluruh anggota dewan komisaris. Komite audit diproksikan dengan skala pengukuran rasio sebagai berikut:

$$
\text { KOMAU }=\quad \text { Jumlah anggota komite audit }
$$

Seluruh anggota dewan komisaris

Nilai perusahaan sebagai variabel dependen diukur dengan menggunakan Tobin's Q yang dihitung menggunakan rumus:

$$
\mathrm{Q}=\frac{\mathrm{MVE}+\mathrm{D}}{\mathrm{BVE}+\mathrm{D}}
$$

Di mana:

$$
\begin{array}{ll}
\mathrm{Q} & =\text { Nilai perusahaan } \\
\mathrm{MVE} & =\text { Nilai pasar ekuitas (Equity Market Value) } \\
\mathrm{D} & =\text { Nilai buku dari total hutang } \\
\mathrm{BVE} & =\text { Nilai buku dari ekuitas (Equity Book Value) }
\end{array}
$$

Keterangan: MVE diperoleh dari hasil perkalian harga saham dan penutupan (closing price) akhir tahun dengan jumlah saham yang beredar pada akhir tahun. BVE diperoleh dari selisih total asset perusahaan dengan total kewajibannya.

Total asset sebagai variabel kontrol diukur dengan besarnya aset perusahaan. Variabel kontrol merupakan variabel yang digunakan untuk melengkapi, atau mengontrol hubungan kausal antara variabel independen dengan variabel dependen, agar mendapatkan model empiris yang lebih lengkap dan lebih baik. Variabel kontrol bukanlah variabel utama yang akan diteliti dan diuji, tetapi lebih ke variabel lain yang mempunyai efek pengaruh (Jogiyanto,2004:157).

Pengujian hipotesis penelitian ini menggunakan teknik analisis regresi berganda. Uji asumsi klasik dilakukan terlebih dahulu sebelum melakukan analisis regresi sederhana. Persamaan regresi penelitian ini adalah sebagai berikut:

$$
\boldsymbol{Y}=\boldsymbol{a}+\mathrm{b} 1 \text { kepin }+\mathrm{b} 2 \text { kepman }+\mathrm{b} 3 \text { komin }+\mathrm{b} 4 \text { komau }+\mathrm{b} 5 \text { totalaset }+\mathbf{e}
$$




\section{Hasil Penelitian dan Pembahasan}

\section{Statistik Deskriptif}

Tabel di bawah ini menampilkan hasil statistik deskriptif dari 81 data perusahaan perbankan yang menjadi sampel.

Tabel 1

Statistik Deskriptif

\begin{tabular}{lccccc}
\hline \hline & $\mathrm{N}$ & Minimum & Maximum & Mean & Std. Deviation \\
\hline Tobinq & 81 & .91 & 1.50 & 1.0658 & .12427 \\
Kepin & 81 & 25.90 & 99.90 & 75.06 & 20.2 \\
Kepman & 81 & 0 & 28.20 & 1.7 & 5.4 \\
Komin & 81 & 0 & 100 & 49.98 & 20.5 \\
Komau & 81 & 20 & 90.90 & 48.1 & 16.9 \\
Totalaset & 81 & 2.54 & 855.04 & 1.3171 & 202.607 \\
Valid N (listwise) & 81 & & & & \\
\hline \hline
\end{tabular}

Berdasarkan tabel 1, rata-rata variabel nilai perusahaan Tobins'q lebih dari 1 yang berarti saham perusahaan yang menjadi sampel dalam kondisi overvalued. Ratarata variabel kepemilikan institusional adalah 75.06 yang berarti proporsi kepemilikan institusionalnya cukup tinggi $(>75 \%)$ sehingga kemampuan dalam mengawasi pihak manajemen juga besar. Rata-rata variabel kepemilikan manajerial adalah 1.7 yang berarti proporsi kepemilikan manajerial rendah, hal tersebut dikarenakan banyak anggota dewan yang tidak memiliki saham di dalam perusahaan. Rata-rata variabel komisaris independen adalah 49.98 yang berarti proporsi komisaris independen kurang dari $50 \%$. Rata-rata variabel komite audit adalah 48.1 yang berarti belum memenuhi peraturan Bank Indonesia yang menetapkan bahwa jumlah minimal adalah 51\%. Ratarata variabel total aset adalah 1.3171 .

Berdasarkan statistik deskriptif diketahui pula bahwa terdapat $29.6 \%$ perusahaan yang memiliki rata-rata skor GCG sebesar 1.0, yang berarti telah menerapkan Good Corporate Governace dengan baik dan terdapat $92.59 \%$ perusahaan yang memiliki rata-rata nilai perusahaan 1.0 atau di atas 1.0 (overvalued) yang berarti manajemen perusahaan berhasil dalam mengelola aktiva perusahaan.

\section{Uji Asumsi Klasik}

Uji asumsi klasik terdiri dari uji autokorelasi, uji heterokedastisitas, dan uji normalitas. Uji autokorelasi bertujuan menguji apakah dalam model regresi linear ada korelasi antara kesalahan pengganggu pada periode $t$ dengan kesalahan pengganggu pada periode t-1 atau sebelumnya. Nilai Durbin Watson dari data yang diuji adalah sebesar 1.707. Nilai ini akan dibandingkan dengan nilai tabel Durbin Watson dengan signifikansi 5\%, jumlah sampel sebanyak $81(\mathrm{n})$ dan jumlah variabel dependen $1(\mathrm{k}=1)$, sehingga didapat nilai dL 1.537 dan dU 1.743. Jika nilai DW sebesar 1.707, maka besar dari batas atas (dU) 1.743 dan kurang dari 4-1.743 (4-dU), maka dapat disimpulkan tidak ada autokorelasi positif maupun negatif atau dapat disimpulkan tidak terdapat autokorelasi. Uji heteroskedastisitas bertujuan menguji apakah dalam model regresi terjadi ketidaksamaan variance dari residual satu pengamatan ke pengamatan yang lain. 
Berdasarkan grafik scatterplot, tidak ada pola yang jelas serta titik-titik menyebar di atas dan di bawah angka 0 pada sumbu Y, maka tidak terjadi heteroskedastisitas. Uji normalitas bertujuan untuk menguji apakah dalam model regresi, variabel pengganggu atau residual memiliki distribusi normal. Berdasarkan hasil uji K-S didapat nilai Klomogrov-Smirnov nilai asymp Sig (2 tailed) adalah 0.06, lebih dari 0.05, sehingga dapat disimpulkan bahwa data terdistribusi secara normal.

\section{Pengujian Hipotesis dan Pembahasan}

Tabel 2 di bawah ini menampilkan hasil dari pengujian regresi linier berganda dari data yang diuji pada tahun 2012 sampai 2014, setelah data nomor 4, 21 dan 24 dibuang karena dianggap sebagai outlier data.

Tabel 2

Ringkasan hasil uji Regresi Linier Berganda Pengaruh Good Corporate Governance terhadap Nilai Perusahaan

\begin{tabular}{|c|c|c|c|}
\hline Variabel & $\beta$ & $\mathbf{T}$ & Sig \\
\hline Constant & & 17.119 & .000 \\
\hline Kepin & -.010 & -.071 & .943 \\
\hline Kepman & -.227 & -1.711 & .091 \\
\hline Komin & -.068 & -.610 & .544 \\
\hline Komau & .140 & 1.201 & .234 \\
\hline Totalaset & .282 & 2.522 & .014 \\
\hline $\mathrm{F}=2.693$ & $\begin{array}{c}\text { Sig } \\
\mathrm{Has}\end{array}$ & $\begin{array}{l}.28 \\
\text { ggolaha }\end{array}$ & $\operatorname{AdjstR}^{2}=0.101$ \\
\hline
\end{tabular}

Berdasarkan hasil output SPSS pada tabel 2 didapatkan koefisien determinasi $\left(\mathrm{R}^{2}\right)$ atau Adjusted $\mathrm{R}$ Square sebesar 0.101, hal ini menunjukan bahwa $10.1 \%$ variasi nilai perusahaan dapat dijelaskan oleh variasi variabel independen: Kepemilikan Institusional, Kepemilikan Manajerial, Kualitas Audit, dan Komisaris Independen. Sedangkan sisanya sebesar $89.9 \%$ dijelaskan oleh sebab-sebab lain di luar model.

Hasil uji regresi linier berganda menunjukkan bahwa pada tingkat signifikansi 0,05, H1, H2, H3 dan H4 tidak dapat diterima. Dengan demikian GCG tidak berpengaruh terhadap nilai perusahaan. Hasil uji menunjukkan bahwa kepemilikan institusional, kepemilikan manajerial dan komisaris independen berpengaruh negatif tidak signifikan terhadap nilai perusahaan, sedangkan komite audit berpengaruh positif tidak signifikan terhadap nilai perusahaan.

Kepemilikan manajerial dan kepemilikan institusional memiliki peranan penting pada perusahaan perbankan sebagai salah satu sumber modal perusahaan, namun hal ini tidak cukup memberikan nilai tambah bagi perusahaan. Banyaknya jumlah komisaris independen dan komite audit juga belum dapat menjadi jaminan untuk meningkatkan nilai perusahaan.

Berdasarkan statistik deskriptif, diketahui bahwa terdapat $62,96 \%$ perusahaan yang memiliki rata-rata nilai perusahaan 1.0 atau di atas 1.0 (overvalued) meskipun rata-rata skor GCGnya kurang dari 1.0. Hal ini berarti terdapat $62,96 \%$ perusahaan yang berkinerja baik meskipun belum menerapkan GCG sepenuhnya. Dengan demikian ada faktor-faktor lain yang mempengaruhi nilai perusahaan. 


\section{Simpulan dan Saran}

Dari pengujian hipotesis dapat disimpulkan bahwa GCG tidak berpengaruh terhadap nilai perusahaan perbankan, hal ini ditunjukan dari hasil pengujian keempat hipotesis yang menyatakan bahwa tidak ada variabel yang berpengaruh secara signifikan. Hasil dari penerapan GCG masih belum terlihat dengan jelas berdampak pada nilai perusahaan. Dengan demikian walaupun penerapan GCG penting bagi perusahaan, namun belum cukup untuk mempengaruhi nilai suatu perusahaan.

Disarankan bagi perusahaan perbankan agar tidak hanya mengandalkan praktek GCG untuk menaikkan nilai perusahaan. Bagi pihak investor yang ingin menanamkan modal di perusahaan perbankan dapat melihat faktor lain seperti, kinerja perusahaan ataupun fluktuasi harga saham perusahaan, karena dengan diterapkannya praktek GCG saja masih belum bisa mempengaruhi nilai sebuah perusahaan.

Keterbatasan dalam penelitian ini adalah data mengenai GCG masih belum bisa menggambarkan penerapan GCG perusahaan yang sebenarnya. Penelitian selanjutnya dapat menggunakan penerapan prinsip-prinsip GCG (transparansi, akuntabilitas, responsibilitas, indepedensi serta kewajaran dan kesetaraan) sebagai indikator serta tingkat kesehatan bank sebagai variabel independen.

\section{Daftar Pustaka}

Balsam, S., Bartov, E. dan Marquardt, C., 2002, "Accrual Management, Investor Sophisticated, and Equity Valuation: Evidence from 10-Q Fillings", Journal of Accounting Research, Vol. 40, No.4, pp. 987-1012.

Black, Bernard S., Jang, H. dan Kim, W., 2003, "Does Corporate Governance affect Firm Value? Evidence from Korea”. http://papers. ssrn.com

Boediono, Gideon, 2005, "Kualitas Laba: Studi Pengaruh Mekanisme Corporate Governance dan Dampak Manajemen Laba dengan Menggunakan Analisis Jalur”, Simposium Nasional Akuntansi (SNA) VIII Solo.

Faisal, 2005, "Analisis Agency Cost, Struktur Kepemilikan dan Mekanisme Corporate Governance". Jurnal Riset Akuntansi Indonesia, Volume 8, No.2, Hal. 175-190.

Jamie, 2014, "GC Watch 2014-Market Rankings", Asian Corporate Governance Association (ACGA)

Jensen, Michael C. dan Meckling, W.H., 1976, "Theory of the Firm: Managerial Behavior, Agency Cost and Ownership Structure", Journal of Financial Economics 3, pp. 305-360.

Jogiyanto, 2004, "Metodologi Penelitian Bisnis: Salah Kaprah dan PengalamanPengalaman", Yogyakarta: BPFE

Listyo, B., 2013, "Pengaruh Mekanisme Good Corporate Governace terhadap Kinerja Perbankan yang terdaftar di BEI 2009-2011", Fakultas Ekonomi, Universitas Negeri Semarang

Lutfiah, A., 2012, "Pengaruh Good Corporate Governance dengan Nilai Perusahaan dengan Pengungkapan Corporate Social Responsibility sebagai Variabel Pemoderasi”, Universitas Negeri Surabaya.

Morck, R. dan Shleifer, A., and Vishny, R.W., 1988, "Management Ownership and Market Valuation: An Empirical Analysis", Journal of Financial Economics, 20, pp. 293-315. 
Ningsih, H. R., 2013, "Pengaruh Kepemilikan Manajerial dan Rasio Pengembalian Aktiva terhadap Nilai Perusahaan" (Studi Kasus Pada Industri Perbankan yang terdaftar di Bursa Efek Indonesia), Jurnal Universitas Komputer Indonesia.

Peraturan Bank Indonesia (PBI) No. 8/4/PBI/2006 tanggal 30 Januari 2006 tentang Pelaksanaan Good Corporate Governance Bagi Bank Umum

Prinsip Dasar Pedoman Good Corporate Governance, 2013, Komite Nasional Kebijakan Governance (KNKG).

Purwaningtyas, F. P. dan Pangestuti, I. R. D., 2101, "Analisis Pengaruh Mekanisme Good Corporate Governance Terhadap Nilai Perusahaan" (Studi Empiris Pada Perusahaan Manufaktur yang Terdaftar pada BEI tahun 2007-2009), Jurnal Akuntansi.

Qorib, F., 2013, "BI Sebut Empat Bank Tak Terapkan GCG". http://www.hukumonline.com/berita/baca/lt51c7fdb93a6c2/bi-sebut-empatbank-tak-terapkan-gcg., Diakses tanggal 10 Maret 2017.

Rachman, A. A., 2012, "Pengaruh Corporate Social Responsibility, Kepemilikan Manajerial, dan Kepemilikan Institusional terhadap Nilai Perusahaan pada perusahaan manufaktur yang terdaftar di BEI tahun 2008-2010”, Jurnal Sekolah Tinggi Ilmu Ekonomi Surabaya.

Randy, V., dan Juniarti, 2014, "Pengaruh Penerapan Good Corporate Governance terhadap Nilai Perusahaan yang terdaftar di BEI tahun 2007-2011“, Akuntansi Bisnis. Universitas Kristen Petra.

Salim, I., 2005, “Komite Audit: Peran yang Diharapkan dan Sejauh Mana Eksistensinya", Fakultas Ekonomi. Universitas Indonesia.

Sari, I., 2010, "Pengaruh Mekanisme Good Corporate Governance Terhadap Kinerja Perbankan Nasional", Skripsi Fakultas Ekonomi, Universitas Diponegoro.

Sheifer, A dan Vishny, R.W., 1997, "A Survey of Corporate Governance", Journal of Finance. Vol 52, No.2 Juni, pp. 737-783.

Silveira, Alexndre Di Miceli D. dan Barros, Lucas Ayres B. de C., 2006, "Corporate Governace Quality and Firm Value in Brazil". Working Paper.

Wahidahwati, 2002, "Pengaruh Kepemilikan Manajerial dan Kepemilikan Institusional pada Kebijakan Hutang Perusahaan: Sebuah Perspektif Theory Agency". Jurnal Riset Akuntansi Indonesia, Vol 5, No. 1.

Walsh, James P. dan Seward, James P., (1990), "On the Efficiency of Intenal and External Corporate Control Mechanism, Academy of Management Review 15, pp. 421-428.

Zulkifli, A.H. dan Samad, F.A, 2007, "Corporate Governance and Performance of Banking Firms: Evidence from Asian Emerging Markets", Advances in Financial Economics, Vol.12, pp.49-74, Oxford: Elsevier. 